\title{
Financial Well-Being Program Development
}

\author{
Elizabeth R. Click, DNP, ND, RN, CWP \\ Mary Ann Dobbins, MEd \\ Case Western Reserve University
}

\begin{abstract}
Background: The impact of financial well-being on health is significant. Research connects individual and organizational well-being to the strength of financial knowledge and sound finance practices among employees. Learning more about financial topics is critical for comprehensive well-being yet few articles exist which describe implementation of such initiatives within organizations.

Aim: While traditional worksite wellness programs have emphasized physical activity, stress management and nutrition, an increasingly larger number of organizations want to expand beyond those categories to topics such as community health and financial well-being.

Methods: A Midwestern research-intensive university has offered financial well-being programs for faculty and staff over the last three years. A description of the initiative, and each programming effort, is included within this article.
\end{abstract}

Results: Numerous positive, qualitative outcomes have been experienced by program participants.

Conclusions: Learn more about the evidence and practical efforts easily implemented within higher education institutions through this description of one university's program experience and outcomes.

Submitted 3 September 2019: accepted 12 November 2019

Keywords: finance, financial health, well-being, wellness

Wellness programs traditionally focus on lowering health risks, keeping people healthy, decreasing absenteeism, improving morale, and reducing medical costs with a growing interest in increasing productivity. Recognition of the individual and organizational impact made when people are present, energized for work and ready to tackle their responsibilities with zest has grown due to research in the field and positive organizational results (Burton, Chen, Liu, Schultz, Kasiarz, \& Edington, 2014; Sherman \& Lynch, 2014). Recent focus on well-being parameters has given organizations greater insight into overall health of the employee population and represents a newer way to establish a culture of health within a worksite.

Gallup-Healthways Well-Being Index data indicates that well-being is composed of five components: Physical, social, career, financial, and community well-being (Rath \& Harter, 2010, 2014). While the impact of chronic disease on productivity is significant, research shows that overall feeling of well-being has an even greater influence (Gandy, Coverley, Pope, Wells, \& Rula, 2014). The majority of wellness programs have focused on physical and social wellbeing, yet far fewer have emphasized financial, community, or career well-being. Awareness of the significant impact of financial well-being on peoples' lives has grown in recent years. Organizations are now creating financial wellness initiatives based on data and professional organization recommendations in the U.S. (Winick, 2019). 
Numerous reports describe the large percentage of adults experiencing financial stress. The American Psychological Association (APA) found that approximately three-quarters of adults feel stressed about money at least some of the time and one-quarter experience extreme financial stress on a regular basis (APA, 2015). The majority of adults in the United States (U.S.) report challenges in paying bills (Consumer Financial Protection Bureau [CFPB], 2017). Statistics indicate that approximately four out of 10 adults would have difficulty covering an unexpected expense of $\$ 400$ and more than one-fifth of adults cannot pay all of their monthly bills (Board of Governors of the Federal Reserve System, 2018). The federal government has found that the majority of U.S. adults with retirement accounts do not feel comfortable managing that money and one-fifth of adults surveyed were not successful in answering financial literacy questions (Moore, 2018). Surveys reveal that financial stress impacts work productivity for one-third of U.S. employees (Clark, 2014; PricewaterhouseCoopers [PWC], 2019). When faced with financial concerns, many employees choose to use work time to investigate solutions which further hampers workplace productivity.

\section{IMPACT OF FINANCIAL STRESS ON HEALTH}

Most stressors, including financial ones, create cumulative effects. The comprehensive effects of financial stress, as described by Bonner (2016) impact health, absenteeism, presenteeism and the quality of relationships. Over time, without mitigation, the stress overload may be significant enough to negatively impact peoples' lives. Health and finances are interconnected in a variety of ways. Recent events in the U.S., over the last 10 years, have compromised the finances of many individuals and have created debt that is challenging to manage. Research describes the serious, negative effects associated with such financial issues (Sweet, Nandi, Adam, \& McDade, 2013). The health consequences of those situations may include physical and mental health effects such as poor subjective health, suicidal thoughts, and depression (Turunen \& Hiilamo, 2014). Approximately 25\% of adults and 33\% of millennials report experiencing symptoms similar to post-traumatic stress disorder due to financial stress (Buckwalter \& Herman, 2016).

The increase in health issues related to poor finances may exacerbate those issues further through the need for more health care and related expenses. Research supports a link between financial savings and healthy lifestyle habits as well as an association between better health and less health care expense (APA, 2015). Living a long and healthy life is important to most people. Learning how to maintain and increase health and well-being is critical to reaching that goal. Equally important is learning how to manage and grow finances so that resources last over one's lifetime. The significant and serious health effects related to financial stress warrant counseling and education to facilitate remediation.

\section{IMPACT OF FINANCIAL EDUCATION ON FINANCIAL STRESS}

Increased knowledge and awareness, through financial education, may alleviate financial stress (Buckwalter \& Herman, 2016). When people feel able to pay bills and meet financial obligations, the likelihood of experiencing financial stress is lower and people feel more secure. Gallup studies have found that financial security has a more significant impact than does income alone on employee well-being (Rath \& Harter, 2014). The positive potential for financial education is great. 


\section{UNDERSTANDING FINANCIAL WELL-BEING}

Financial well-being has been described as having financial security and financial freedom of choice now and in the future. A recent survey of U.S. adult employees revealed definitions focused on not feeling stress in relation to money, not having debt, having enough savings, being able to afford routine life expenses, being able to retire when desired, and feeling free to make choices that increase life enjoyment (PWC, 2019). Examples include: Having control over daily finances, being able to absorb financial issues as they arise, having financial goals and working towards them while using free will regarding options (CFPB, 2015a). Learning how to live within one's means, gathering useful information by asking questions, taking action to prepare for success, and maintaining a future focus are all practical strategies to pursue and achieve financial well-being. Knowing the right questions to ask to plan for one's financial future while being empowered and capable of using that knowledge to take positive action are all critical abilities that support financial well-being. Personal traits are also important when describing this concept. Having the appropriate executive functioning skills to delay gratification and plan for the future, maintain focus on one's personal situation rather than comparing to others, having strong financial self-efficacy (e.g., believing in one's ability to manage financial outcomes well), and persevering with goals and actions in the face of obstacles are characteristics that positively influence overall financial well-being (CFPB, 2015b). These goals are consistent with the U.S. National Strategy for Financial Literacy vision focused on sustained financial well-being for individuals and families (FLEC, 2011).

Given the significant impact of financial stress on peoples' lives and the great deal of time that people spend at work, employers have many reasons to provide financial education and promote financial well-being. Helping individuals manage current financial stressors will help increase expectations for future financial security. Providing comprehensive education to address knowledge deficiencies is an excellent strategy for employers to help their employees and expand financial and overall well-being within their population (Netemeyer, Warmath, Fernandes, \& Lynch, 2017). The known benefits coupled with productivity gains, benefits to employee health, with related health care cost advantages, are all reasons why employers should pursue this type of worksite wellness program.

\section{FINANCIAL EDUCATION STRUCTURE}

Providing financial education at work is an effective strategy to strengthen financial literacy and positively affect behavior (Kaiser \& Menkhoff, 2017; Xiao \& O’Neill, 2017). Although there are challenges in meeting the educational needs of all income levels, persistent and consistent educational offerings are helpful in addressing the needs of many U.S. adults.

The National Strategy goals provide an excellent structure upon which financial education programs can be based (FLEC, 2011). The U.S. Chamber of Commerce Foundation has provided best practice suggestions for workplacebased financial well-being programs (Zellner, 2018). Strategies for success have also been reported by Prudential (Winick, 2019). Specific strategies focused on Ask, Plan, and Act strategies have been emphasized (CFPB, 2015b). ln addition to sharing key content, the impact of motivation stemming from education, addressing individual needs as much as possible, and the opportunity for skills practice have been identified as important educational strategies (Peeters, Rijk, Soetens, Storms, \& Hermans, 2018).

Managing personal finances well significantly contributes to feelings of financial security. Being satisfied with

one's overall standard of living, spending money wisely, giving to others as well as spending money on oneself, and spending money on experiences that create lasting memories are all ways to enhance financial well-being. Taking an 
active role in learning more about finances is associated with less stress, increased feelings of security, improved family relationships, and greater confidence and capability (Drake, O’Neil, \& Hoffmire, 2019; PWC, 2019; Xiao \& O’Neill, 2016).

To maximize well-being, these best practice principles guided development of a university financial well-being education program. The university-based wellness program progressed from an emphasis on core wellness areas, such as physical activity, stress management, weight management, nutrition, and tobacco cessation, while expanding into financial well-being. This novel approach to worksite wellness propelled the organization beyond a traditional wellness program into the realm of well-being. Given the sparse nature of published literature detailing implementation of avant-garde well-being programs, this article describes experiences of one university in implementing a financial wellbeing initiative.

\section{UNIVERSITY FINANCIAL WELL-BEING PROGRAM AND INCENTIVE STRUCTURE}

One Midwestern research-intensive university worksite wellness program initiated an incentive program in 2014 for benefits-eligible faculty and staff (Click, 2017). After focusing on lifestyle behavioral categories such as physical activity, weight management and nutrition, stress management, and tobacco cessation, the program expanded to include financial and community well-being (Click, Hammock, Omabegho, \& Kowal-Smith, 2019). Faculty and staff that completed three activities prior to the new calendar year, and using one of the university's medical plans, received the baseline monthly incentive ( $\$ 25$ per month) and were eligible for additional incentives of $\$ 100$ for one program, or $\$ 200$ for two programs, during the year. Participation guidelines for financial well-being focused on participation in a multi-session program to learn more about financial management. Attending at least seven of eight sessions of a multi-week program that increased knowledge and capability in managing finances met the participation guidelines for this incentive. After meeting those guidelines, wellness program participants needed to complete an online form to formally attest to eligibility for the financial well-being program incentive.

\section{PROGRAM IMPLEMENTATION}

In 2015, a pilot program was developed and implemented to assess interest in financial health topics. General themes of saving and investing for retirement were addressed. Significant interest was evident with 100 participants attending the sessions. Using that participation data along with positive evaluation feedback and a sound, evidence-based approach, a proposal was shared with leadership. Initiation of the new Financial Well-being Program Incentive category began in 2016. A key success factor with this program was that a respected Business School faculty member, with extensive experience providing financial health education within academia as well as the community, served as the educator. The unbiased nature of his comments, and his use of current statistics and financial strategies, helped build credibility in the program from the beginning. By 2017, significant interest and positive evaluations led to the development of a " 2.0 " presentation series so that additional financial information could be shared. During one summer, a four week-long online challenge was offered through one of the university's retirement plan vendors. Utilizing a gamification approach, participants had daily opportunities to answer financial questions and become eligible for various raffle prizes. Prior to these sessions, the only financially focused education sessions offered on campus focused on retirement. Retirement plans are offered for university faculty and staff through two vendors. Both vendors offer individual financial counseling on campus a number of days each month. This financial planning 
focuses exclusively on retirement fund investments and does not address the broad financial well-being topics covered in the series described in this paper. All of these strategies are consistent with financial wellness benefits desired by adults from their employer (PWC, 2019).

\section{PROGRAM PARTICIPATION}

Over four and a half years, 14 different sessions have been offered on campus. In addition, three series were offered by the university retirement investment vendors. Generally, the campus series were eight weeks in length, one hour each week. One hybrid session was offered in 2018 with four weekly in-person, on-campus sessions and four online video webinars (available through the university's Employee Assistance Program [EAP] vendor). In addition, one four-week long online challenge was offered in 2017. Total participation numbers are described (Table 1).

Table 1

Annual Participation Numbers

\begin{tabular}{|cccccc|}
\hline & 2019 & 2018 & 2017 & 2016 & 2015 \\
$\begin{array}{c}\text { Financial Well- } \\
\text { Being Program } \\
\text { Participants }\end{array}$ & 212 & $144^{*}$ & 237 & 162 & 100 \\
Total Annual & 2,248 & 1868 & 1449 & 1516 & 1337 \\
$\begin{array}{c}\text { Participation } \\
\text { Well-being } \\
\text { Program }\end{array}$ & & & & & \\
Financial & $9 \%$ & $8 \%$ & $16 \%$ & $11 \%$ & $7 \%$ \\
Participation as & & & & & \\
\% of Annual & & & & & \\
Participation & & & & & \\
\hline
\end{tabular}

*In 2018, two sessions had to be cancelled at the last minute with no option to find a different instructor. Otherwise the participation would have been on par with 2017.

Although more females attended than males, this program category attracts more men than do other wellness program topics offered on campus (Table 2). As seen within other program categories, more exempt and non-exempt staff, than faculty, have participated in these sessions. Program topics are listed (Table 3). 
Table 2

Gender Participation Numbers (2016-2018)

\begin{tabular}{|lcc|}
\hline $\begin{array}{l}\text { Program } \\
\text { Finance Series } \\
\text { (onsite/8 weeks) }\end{array}$ & Female Participation & Male Participation \\
$\begin{array}{l}\text { Meditation Series } \\
\text { (onsite/8 weeks) }\end{array}$ & $501(81 \%)$ & $52(15 \%)$ \\
$\begin{array}{l}\text { Nutrition Series } \\
\text { (onsite/8 weeks) } \\
\text { Yoga Series } \\
\text { (onsite/6 weeks) }\end{array}$ & $300(85 \%)$ & $38(11 \%)$ \\
\hline
\end{tabular}

Table 3

Program Topics

Financial Well-being 101

\section{Financial Well-being 101}

- Building a Budget

- Retirement

- Saving More

- Investments

- Life and Disability Insurance

- Property and Casualty and Liability Insurance

- Credit Scores

- Buying or Leasing a Car

\section{Financial Well-being 201}

- Choosing a Financial Advisor

- Smart Ways to Pay Off Debt

- Savings for College

- Health Insurance

- Estate Planning Basics

- Individual Tax Basics

- How Social Security Works

- How to Use Credit Cards 


\section{PROGRAM EVALUATION}

Post-participation qualitative feedback statements reveal significant, positive impact associated with session attendance and implementation of knowledge.

"I love that we learn the big picture - how it works, why it works, who benefits, trade-offs, and examples to make it apply."

"The class as a whole gave me an understanding of personal finances that I have been able to find nowhere else."

"The unbiased approach has been greatly appreciated."

"Thinking more about my savings goals has been helpful - it makes the goals more tangible. Attending these seminars felt like an active way to participate in my retirement savings (more active than just watching the money get deposited from each paycheck)."

"The encouragement to do a budget and reassess periodically. Also when the speakers talked about the importance of investing more now into retirement while still paying down debt. While I am already investing in retirement, I was putting less money there so that I can pay off my school loans more quickly. I see now that I really should increase what I save at the same time as paying down that debt."

\section{SUCCESS STORIES}

The university regularly highlights success stories from individuals that participate in programs. One of those people shared:

"Both of the Financial Wellness series helped me to understand finances on a broader level and begin to see that I could make minor changes to get to where I needed to be financially. The courses are very diverse, but I realized that by attending them all I would understand things that I need to know in my life now and understand things that would not apply to my life until the future.

I now understand a host of financial terms and what each is for and how it applies to me. is a great instructor who is plain spoken and easy to approach.

Because I slowly started to improve my retirement savings through my 403B I got a bonus of $\$ 200$ on my tax refund. So along with the program bonus of $\$ 100$, this class has been well worth my time and improved my finances in many ways.

I encourage everyone to take his courses because they pay now and in the long term. There are not very many things in life that can do that."

\section{INTERESTING INSIGHTS}

As the program continued, it has been clear that many participants benefit from additional information about the different retirement programs available within the university. During one of the 2018 series, a one hour presentation was developed and delivered to share that material. Shorter series, over three and four weeks, have offered additional retirement-focused sessions.

Using unbiased, dynamic presenters makes the content more appealing for diverse audiences. The quality of each presentation has been highly dependent on the presenter's style and demeanor. Identifying presenters that connect 
well with an audience and who promote engagement with the content, and using them more frequently has led to more positive evaluations overall. Providing the opportunity for group education, while offering individual consultation via retirement plan vendors, meets a wide variety of needs.

\section{FUTURE DIRECTIONS}

Meeting employee financial well-being needs at the workplace adds value for individuals by decreasing stress associated with inadequate knowledge, and promotes engagement at work. The positive experiences described within this university program suggest that consideration be given to implementation within other worksites. Increasing accessibility to this important content will increase the likelihood that more individuals and organizations will experience similar benefits associated with financial well-being. 


\section{REFERENCES}

American Psychological Association (APA; 2015). Stress in America TM Paying with our health. American Psychological Association Press. Downloaded on July 20, 2018 from http://www.apa.org/news/press/releases/stress/2014/stress-report.pdf.

Board of Governors of the Federal Reserve System. (2018). Report on the economic well-being of U.S. households in 2017. Downloaded on July 20, 2018 from https:/ /www.federalreserve.gov/publications/files/2017-report-economic-well-being-us-households201805.pdf.

Bonner, P.A. (2016). The impacts of financial stress on your employees. Plans \& Trusts, 18-24.

Buckwalter, G., \& Herman, D. (2016). The pay off financial stress index. Alternet, 1-17.

Burton, W.N., Chen, C.Y., Li, X., Schultz, A.B., Kasiarz, D., \& Edington, D.W. (2014). Evaluation of a comprehensive employee wellness program at an organization with a consumer-directed health plan. Journal of Occupational \& Environmental Medicine, 56(4) 347-353. https://doi.org/10.1097/JOM.0000000000000121

Clark, A.D. (2014). Financial stress: A workplace epidemic. Benefits Magazine, 32-35.

Click, E. R. (2017). Creating a culture of health - One university's experience. In A. Frame (Content Ed.) Health Matrix: Journal of Law-Medicine, 27, 417-434.

Click, E.R., Hammock, J.M., Omabegho, B., \& Kowal-Smith, A. (2019). Developing community relationships to enhance well-being in a worksite wellness program. Public Health Nursing, 36(3), 363-369. https://doi.org/10.1111/phn.12605

Consumer Financial Protection Bureau. (2015a). Financial well-being: What it means and how to help. Downloaded on July 20, 2018 from https://files.consumerfinance.gov/f/201501_cfpb_digest_financial-well-being.pdf.

Consumer Financial Protection Bureau. (2015b). Financial well-being: The goal of financial education. Downloaded on July 20, 2018 from https:// files.consumerfinance.gov/f/201501_cfpb_report_financialwell-being.pdf.

Consumer Financial Protection Bureau. (2017). Financial wellbeing in America. Downloaded August 7, 2019 from https:/ /files.consumerfinance.gov/f/documents/201709_cfpb_financial-well-being-in-America.pdf.

Drake, D.S., O’Neil, T., \& Hoffmire, J.S. (2019). Financial wellness at Meredith Corporation. American Journal of Health Promotion, 33(1), 153-155. https://doi.org/10.1177/0890117118812822d

Financial Literacy and Education Commission. (2011). Promoting financial success in the United States: National Strategy for Financial Literacy. Downloaded July 20, 2018 from https://www.treasury.gov/resourcecenter/financialeducation/Documents/NationalStrategyBook_12310 20(2).pdf. 
Gandy, W.M., Coberley, C., Pope, J.E., Welles, A., \& Rula, E.Y. (2014). Comparing the contributions of well-being and disease status to employee productivity. Journal of Occupational and Environmental Medicine, 56(3), 252-257. https://doi.org/10.1097/JOM.0000000000000109

Kaiser, T., \& Menkhoff, L. (2017). Does financial education impact financial literacy and financial behavior, and if so, when? The World Bank Economic Review, 31(3), 611-630. https://doi.org/10.1093/wber/lhx018

Moore, R. (2018). Fed report suggests more investing and financial education needed. Plan Advisor, 5/23/2018, 24.

Netemeyer, R.G., Warmath, D., Fernandes, D., \& Lynch, J. G. (2017). How am I doing? Perceived financial wellbeing, its potential antecedents, and its relation to overall well-being. Journal of Consumer Research, 45, 6889. https://doi.org/10.1093/jcr/ucx109

Peeters, N., Rijk, B., Soetens, B., Storms, B., \& Hermans, K. (2018). A systematic literature review to identify successful elements for financial education and counseling in groups. The Journal of Consumer Affairs, 52(2), 415-440. https://doi.org/10.1111/joca.12180

PricewaterhouseCoopers. (2019). Special report: Financial stress and the bottom line. Downloaded on August 7 , 2019 from https://www.pwc.com/us/en/private-company-services/publications/assets/pwc-2019employee-wellness-survey.pdf.

Rath, T., \& Harter, J. (2010). The economics of wellbeing. Washington D.C.: Gallup Press.

Rath, T., \& Harter, J. (2014). Well-being: The five essential elements. New York, NY: GallupPress.

Sherman, B., \& Lynch, W. (2014). Connecting the dots: Examining the link between workforce health and business performance. American Journal of Managed Care, 20, 15-120.

Sweet, E., Nandi, A., Adam, E.K., \& McDade, T.W. (2013). The high price of debt: Household financial debt and its impact on mental and physical health. Social Science \& Medicine, 91, 94-100.

https://doi.org/10.1016/j.socscimed.2013.05.009

Turunen, E., \& Hiilamo, H. (2014). Health effects of indebtedness: A systematic review. BMC Public Health, 14, 489-496. https://doi.org/10.1186/1471-2458-14-489

Winick, K. (2019). Pioneering workplace financial wellness. American Journal of Health Promotion, 33(1), 151 153. https://doi.org/10.1177/0890117118812822c

Xiao, J.J., \& O’Neill, B. (2017). Consumer financial education and financial capability. International Journal of Consumer Studies, 40, 712-721. https://doi.org/10.1111/ijcs.12285

Zellner, S. (2018). Financial wellness in the workplace: The business imperative. U.S. Chamber of Commerce Foundation. Downloaded on August 7, 2019 from https://www.uschamberfoundation.org/sites/default/files/Financial\%20Wellness $\% 20$ Paper $\% 20$ Layout $\% 2$ 0Final $\% 20$ For $\% 20$ Website.pdf. 
Author correspondence may be addressed to:

Elizabeth R. Click, DNP, ND, RN, CWP

Medical Director

Assistant Professor, Frances Payne Bolton School of Nursing

Case Western Reserve University

10900 Euclid Avenue

Cleveland, $\mathrm{OH} 44106$

erc10@case.edu

Mary Ann Dobbins, MEd

mxd490@case.edu

Wellness Manger 